\title{
EGY ÚJGENERÁCIÓS TÖRTÉNELEM TANKÖNYV MINTALECKÉJÉNEK VIZSGÁLATA AZ IPOO-MODELL SZEMPONTJÁBÓL
}

Szerző:

Kamp Alfréd

Eszterházy Károly Egyetem, OFI

Első szerző e-mail címe:

kamp.alfred@ofi.hu

\author{
Lektorok:
}

\author{
Dr. habil Kaposi József \\ Pázmány Péter Katolikus Egyetem
}
Dr. Koncz István
Professzorok az Európai Magyarországért
Egyesület

Kamp Alfréd (2018): Egy újgenerációs történelem tankönyv mintaleckéjének vizsgálata az IPOO-modell szempontjából. Különleges Bánásmód, IV. évf. 2018/2. szám, 7-16. DOI 10.18458/KB.2018.2.7

\begin{abstract}
Absztrakt
A tankönyv nélkülözhetetlen taneszköz az egyes tantárgyak tanitási-tanulási folyamatában. Ez a tanulmány megvizsgálja, hogy egy új fejlesztésü hazai történelem tankönyv mintafejezete mennyiben felel meg az IPOO tanulási modellben körvonalazott tanulási fázisoknak, és javaslatokat tesz a választott tankönyvnek a történelemórákon történö hatékony felhasználására.
\end{abstract}

Kulcsszavak: történelemtanítás, tankönyv, IPOO-modell, tanuláselmélet

Diszciplina: pedagógia

\begin{abstract}
Textbooks are essential teaching tools in the teaching-learning process in certain subjects. This study examines whether a newly developed national history textbook's sample chapter can meet the requirements of the learning stages outlined in the learning model of IPOO, and makes suggestions for the effective use of the chosen textbook through History lessons.
\end{abstract}

Keywords: history teaching, textbook, IPOO-model, learning theory

Discipline: pedagogy

\section{Tanuláselméletek és tanulási modellek}

A különböző tanuláselméletek a tanulás meghatározásának sajátos irányait jelzik, és összefoglalják azokat a feltételeket és tényezőket, amelyek a tanulás hatékonyságát befolyásolják. A behaviorizmus középpontjában a kondicionálás áll, e felfogás szerint a tanulás ismétlésre és megerősítésre épül, vagyis a folyamat során a tanár adja át a tananyagot, a tanuló pedig memorizálja azt, majd egy adott séma szerint adja vissza a megtanultakat (Atkinson, 2005). A kognitívizmus szerint az ember a külvilágról modellt épít, e nézet szerint a tanulás során a külvilágban tapasztalható szabályokat sajátítja el a diák. Ezért a tanárnak figyelnie kell arra, hogy megfelelő modellt állítson a diákjai elé akár szavai, akár metakommunikációja által (Nahalka, 2002). A konstruktívizmus álláspontja értelmében a 
tudás nem egy megszerezhető tudatállapot, hanem egy belső kreatív folyamat eredménye, ezért ez az irányzat a tanuláshoz szükséges motivációt vizsgálja, és úgy véli, hogy a tudás nem adható át, viszont fontosnak tartja, hogy kreatív légkört kell létrehozni és fenntartani a tanulócsoportban (Nahalka, 1997). A konnektívizmus elméletében a modern hálózatelméletek szemlélete érhető tetten. Ebben az alapvetően tanulóközpontú nézetben a tanár és a tanuló szerepe jelentősen átalakul, a tanár elsősorban tanulásszervezővé válik, a tanuló pedig jelentős autonómiára tesz szert (Bessenyei, 2007).

A tanulási modellek felállítása során a szervezett körülmények között zajló tanulási folyamatot vizsgálják, legfőképpen a minél sikeresebb tanulást elősegítő tényezőket tanulmányozzák. John. B. Carroll, amerikai pszichológus, belső és külső tényezőket sorakoztatott fel az eredményes és gazdaságos tanulás kialakítása érdekében és elötérbe állította az aktív tanulási idő és a tanuláshoz szükséges kitartás szerepét (Virág, 2014). A tantervi követelmények meghatározásában jelentős elörelépést jelentett a Benjamin Bloom által kidolgozott taxonómia, amely kognitív és affektív követelményszinteket állapít meg az értelmi fejlődés szintjeihez igazodva. Az ő felfogásában is fontos szerepe van a tanulásra fordított időnek, azaz hogy mennyi idő alatt várjuk el az aktuális tananyag elsajátítását a tanulótól.

Mező Ferenc és Mező Katalin 2007-ben tette közzé a tanulásfejlesztés kutatása alapján kidolgozott IPOO (input - process - output - organizáció) tanulási modellt (Mező, 2007). Az elmélet megfogalmazói a tanulást információfeldolgozásként értelmezik, ezért összetevőit is az információkezelés folyamata alapján határozzák meg. Ha a tanulást információkkal való müveleteknek tekintjük, akkor az alábbi fázisokat kell végigjárni, esetenként visszatérve egyegy korábbi fázishoz:

1) információgyüjtés (input);

2) információfeldolgozás (process);

3) információalkalmazás, felhasználás (output) és

4) tanulásszervezés (organizáció), amely az előzőek eredményességét meghatározza.

A fázisok áttekintéséből látszik, hogy a legjobb tanulásszervezés sem helyettesítheti az információkkal történő szükséges müveleteket, ugyanakkor a tanulásszervezés elmaradása a többi összetevő megfelelő jelenléte mellett sem vezethet eredményes tanuláshoz. A négy különböző stádium eredményessége erösítheti, vagy gyengítheti egymás hatását.

\section{A kísérleti tankönyvfejlesztés}

Az Oktatáskutató és Fejlesztő Intézetben az utóbbi évek tankönyvfejlesztési folyamata a TÁMOP 3.1.2-B/13-2013-0001 projekttel indult, melynek alapvető célja az volt, hogy a közoktatás tartalmi kínálatának megújításával, bővítésével, a Nemzeti Alaptantervhez és a kerettantervekhez illeszkedő új típusú tankönyvek és egyéb taneszközök elkészítésével elősegítse a közoktatás minőségének fejlődését, és a meghatározott eredményességi és hatékonysági célok teljesülését. A tartalmi fejlesztés célja egy olyan országosan egységes taneszköz-rendszer kialakítása és iskolákhoz való eljuttatása volt, amely megfelelö feltételt teremt az új tartalmi szabályozókban foglalt követelmények sikeres megvalósításához (Kojanitz, 2014).

A fejlesztés során kitűzött szakmai elvárások között - többek között - rögzítették, hogy

- a kísérleti tankönyvek vegyék figyelembe a tanulók előzetes tudását,

- a szövegek belső tartalma logikailag strukturált legyen, biztosítva a magyarázatok és okfejtések megértését,

- a szerzők vegyék figyelembe a tanuláshoz rendelkezésre álló időt és a tanulók befogadóképességét, 
- a tankönyvek adjanak lehetőséget arra, hogy a tanulók az új ismeretek megszerzése során aktív szerepet kapjanak,

- a tankönyvi leckék ne csak az ismeretátadáson alapuló tanítási stratégiát támogassák, hanem a munkáltató, a problémamegoldó, a projekt-tanítást, valamint a kooperáción alapuló ismeretelsajátítást is,

- a tudáskínáló szövegeken kívül legyenek a tankönyvekben élménykínáló és információkínáló szövegek is,

- a tankönyvi kérdések az ismeretek továbbgondolását és alkalmazását is igényeljék a tanulóktól,

- az új tankönyvek segítsék elő a tanulói tapasztalatok és személyes élmények összekapcsolódását a tanultakkal,

- az tankönyvek adjanak segítséget ahhoz, hogy az internet a tanulás hasznos ismeretforrásává váljon,

- a tankönyvekben jelenjenek meg az adott müveltségterület és tudomány különlegességei és megoldandó problémái.

A projekt keretében a kísérleti tankönyv taníthatóságát és tanulhatóságát valóságos körülmények között, iskolai kipróbálás keretében ellenőrzik és vizsgálják. Az iskolai kipróbálás, elsősorban a tanárok és a diákok észrevételeinek és javaslatainak összegyüjtését és feldolgozását jelenti, melynek alapján átdolgozásra kerülnek a tankönyvek, és így nyerik el végleges tartalmukat (OFI, TÁMOP 3.1.2-B beszámoló).

\section{Tankönyvi lecke vizsgálata az IPOO-modell szempontjai alapján}

Jelen tanulmány célja, hogy felmérje a Történelem 9. újgenerációs tankönyvnek az osztályteremben ill. az önálló tanulási folyamatban betöltött szerepét egy lecke anyagának, $A z$ őskor címü fejezetnek a vizsgálatával (OFI, Történelem 9.). Az IPOO-modell alapvetően az információgazdálkodás módszertanával tekint az ismeretszerzés mechanizmusára. A korábban áttekintett tanulási modell négy fázisát (információgyüjtés, információ feldolgozás, információ visszaadás vagy alkalmazás, tanulásszervezés) megpróbáljuk összevetni az órai ill. az otthoni tanulás folyamatával, amennyiben ezek a tankönyvhöz alapján szerveződnek.

A tankönyv bevezető részében a diák instrukciókat kap az alkotóktól által - egy-egy lecke felépítésénél - használt speciális tördelési jelölések funkciójáról a feldolgozás menetében, ill a könyv hátsó-belső borítóján (B3) Jó tanácsok gyüjteménye található a tankönyvekből történő felkészüléshez. Ez utóbbi - egyébként rendkívül praktikus - tanulás-módszertani ötletek önálló használata nem valószínűsíthető egy átlagos 15 éves diák részéről. Hatékony alkalmazására akkor van remény, ha a szaktanár a tanórán gyakoroltatja és rendszeresen alkalmazza ezeket az eszközöket: például a tankönyv végén található fogalomgyüjteményt és kronológiai táblát beépíti az óra menetébe, sőt feladatokat ad ezekkel kapcsolatban.

\section{Input fázis}

Az IPOO első, Input fázisában az információk összegyüjtése történik. A szervezett körülmények között zajló intézményesített oktatásban a diákok az iskolai tananyag legnagyobb részével élőszavas vagy írott szöveges információ formájában találkoznak a tanórán. A számon kérhető információkat általában a kerettantervek alapján készült tankönyvek szövege tartalmazza, amit a tanári magyarázatok tesznek érthetőbbé. Ez ugyan biztosítja a tananyag norma jellegét, az országosan egységes oktatáshoz való hozzáférést, ugyanakkor az információgyüjtést többnyire a tankönyvi információk feldolgozására korlátozza. Korlátozottan korábban is beépítettek a tanárok más információhordozókat az oktatásba (könyvtár, szakkönyvek, filmek, stb.), de napjainkban, az internethez való egyszerü 
hozzáférés korszakában alapjaiban változott meg ez a kritérium. A történelem tantárgyi kerettantervben is megfogalmazódott az önálló és kritikus kutatási tevékenység fejlesztésének célkitüzése, amihez az interneten beláthatatlan mennyiségü - hiteles és kevésbé hiteles forrás áll rendelkezésre. Vagyis a tankönyvben megjelenő forrástípusok (szöveg, kép, ábra, térkép) bővítési lehetősége rohamosan növekszik a közgyüjtemények digitalizálási tevékenységével párhuzamosan. Külön kiemelhetjük, hogy a 20. század történelmének feldolgozásához rendkívül jól használhatóak a korabeli filmrészletek, a dokumentumfilmek, riportok, visszaemlékezések, de akár a játékfilmek is.

$A z$ őskor c. első leckében - és az egész tankönyvben - az elsődleges információforrás a tanuló számára a könyv gerince mentén található törzsszöveg, amely a későbbi számonkérés elsődleges tárgya. Ugyanakkor a történelem tantárgy keretében fejlesztendő kompetenciák miatt a szerzők további változatos forrástípusokat alkalmaznak a kerettantervben megjelölt célkitüzések elérése érdekében. Két térképen lehet gyakorolni a tájékozódás térben követelményét (A Homo Sapiens szétrajzása / A termékeny félhold); egy $f a$ ábra segít az emberszabású faj bonyolult, elágazásos rendszerének megismerésében; öt táblázatból négynél nemcsak eloszlási adatstruktúrákat, hanem időbeli-fejlődési tendenciákat is felismerhetünk, így alkalmasak a tájékozódás időben gondolkodási müveletének gyakorlására. Öt fénykép a régészeti munka összetettségét érzékelteti változatos leletek bemutatásával, egy 19. századi gúnyrajz (Darwinról) pedig egy tudományos nézet fogadtatásának változását tükrözi.

Fontos módszertani kérdés, hogy a szaktanár mennyiben akarja és tudja - időszükében kiegészíteni egyéb információforrásokkal a tankönyvet, és biztosít-e időkeretet az ellenörizhető és kevésbé hiteles források (könyvtári szakirodalom vs. internetes oldalak) használatának problematikájára.

Az önálló forráshasználat fejlesztését szolgálja, hogy a tankönyvi térképekhez, ábrákhoz, képekhez külön feladatok, kérdések kapcsolódnak, amelyek a levonható következtetések elmélyítésére, kiterjesztésére ösztönzik a diákot az interneten könnyen elérhető adatok felkutatásával, és így az önálló kutatási-elemzési gondolkodásmódot alakíthatják ki (pl. Mely mai országok területén fekszik a termékeny félhold?). A tankönyvi müvelödési anyag kiegészülve a feladatokkal elősegíti, hogy a tanulók további ismereteket szerezzenek önállóan vagy tanári irányítással olvasmányaikból, tömegkommunikációs eszközökből, az internetröl, és tudják készségszinten használni a papíralapú és digitális ismerethordozókat.

Szintén az egyéni kutatómunkát ösztönzik a leckékben visszatérö érdekességek. A föszöveg mellett gyakran megjelenő Rá@dás címü részek a tankönyvhöz tartozó digitális tananyagra utalnak, ahol olyan kiegészítő anyagrészek kaptak helyet (a Nemzeti Köznevelési Portálon), amelyek a könyvbe terjedelmi okokból nem kerülhettek be. A Kitekintö címü részekben szintén olyan történelmi érdekességek találhatók, amelyeket nem kötelező megtanulni, de érdemes elolvasni, mert nemcsak szórakoztatóak, hanem ismeretük az általános müveltséget is gyarapítja.

A tanulás első ciklusában tehát megtörténhet a források megismerése és az információk összegyüjtése.

\section{Process fázis}

Az IPOO második, Process fázisában az információk feldolgozása zajlik. Az információkezelés minőségére utal, hogy három fajta végeredménye lehet a feldolgozási stratégiának. Ha a tanulás során az információ visszaadása kisebb, mint a befogadott információ, akkor improduktív, deficites tanulásról beszélünk. Ha a tanuló ugyanannyi információt ad vissza, mint amennyit megkapott, akkor reproduktív a tanulás. Végül, ha a diák több információt ad vissza, mint amennyi rendelkezésére állt, akkor produktív, kreatív 
tanulás történt. Vagyis el kellene érni, hogy a diák megfelelő jártasságot szerezzen az értő tanulás kialakításában, és ne csak magoljon.

A diák számára az eredményes feldolgozáshoz nélkülözhetetlen, hogy a rendelkezésre álló információhalmazt valamilyen struktúrába rendezze, ezért ehhez akár átszerkesztésre is szükség lehet. Ebben a folyamatban két tényező segíti a tanulót. Egyrészt elsődleges szerepe van a tanárnak, aki az órai tevékenység során a közös munkával összegyüjtött információkat azonnal strukturálhatja például egy táblai vázlat megkonstruálásával, vagy még jobb, ha elöre adott szempontok segítségével a diákok közösen hozzák létre a konstrukciót. A vázlat különböző szempontú összefüggéseket is egybeépíthet (időrend, hierarchia, halmazok, folyamatok), hiszen fontos, hogy a diák számára egyértelmüvé váljanak az ok-okozati viszonyok, a törvényszerüségek. Tapasztalataink szerint a tanárok által elöre elkészített prezentációk gyors pörgetése vagy a vázlatdiktálás a tanórán kevésbé segíti az információk aktív rendezését és átlátását a diákok számára, mint a tanulókkal közösen vagy szinkronban megszerkesztett táblai vázlat.

A másik nagy segítség a tanuló számára az otthoni vagy önálló tanulás esetén a tankönyvi szöveg megfelelő rendezettsége és a gondosan megválasztott tipográfiai eszközök alkalmazása. Az őskor címü lecke is jól prezentálja a tankönyv pedagógiai szempontú tördelését, vagyis a föszöveg elkülönítését, amely a megtanulandó törzsanyagot tartalmazza úgy, hogy a fontosabb ismereteket vastag betüvel szedték, így a lecke vázlatának föbb pontjai kiemelkednek a folyó szövegből (őskor, őskőkor, újkőkor, forrásanyagok, ősember, stb.). Ez a fajta szerkesztésmód már alapkövetelmény egy mai tankönyvtől. A természettudományi tankönyvek mellett a 2005-ös érettségi reform óta már a történelem tankönyvekre is fokozottan jellemző az ábrák, táblázatok, diagramok, grafikonok, térképek alkalmazása (ebben az egy leckében nyolc darab található), amelyek erősítik az értő tanulás hatásfokát: az összefüggések, folyamatok meglátását, az okok és következmények nyilvánvalóvá válását.

Az információk hatékony feldolgozását, a rendszerezett tudás kialakítását egyéb eszközökkel is előmozdítja a tankönyv. Minden lecke végén Összegzés található két-két visszatekintő kérdés formájában: egyrészt a Történelmi forrás, másrészt az Okok és következmények nézőpont fokozatos kialakításához kapcsolódnak a kérdések, amelyek nélkülözhetetlenek a tantárgy tanulását kísérö sajátos gondolkodásmód fejlödéséhez (pl. Mely tudományok segítik az őstörténet feltárását?). Ugyanakkor a tankönyvi témakörök végén megjelenő Összefoglalás lecke is az elmélyítést és a rendszerzést szolgálja azáltal, hogy egyrészt összegző kérdéseket, másrészt vázlatot ad a leckék közös szempontok szerinti rendezéséhez, harmadrészt közli a kerettantervekben szereplő fogalmakat, adatokat a számonkérésre való felkészüléshez.

A tananyag feldolgozását támogatja, hogy a 2012-es Nemzeti alaptanterv előtérbe helyezi a kulcsfogalmakra épülő fogalmi háló alapján történő gondolkodás kialakítását az egyes tantárgyak esetében. „A tanítás meghatározó célja a differenciált történelmi gondolkodás kialakítása, az adatok, tények, fogalmak, a történettudomány által kínált konstrukciók (sémák) rugalmas adaptálásával, illetve a történettudomány vizsgálati eljárásainak (történeti probléma felismerése, megfogalmazása, a kritika, az interpretáció) alkalmazásával."(Njt, NAT). A történelem tantárgy esetében két fajta kulcsfogalomra épít a tanterv. A történelmi tartalmakat kifejező (értelmezó) kulcsfogalmak az egyes jelenségek közös sajátosságainak fogalmi megragadásával segítik a múlt folyamatainak megértését (pl. társadalom, társadalmi osztály, réteg, állam, államforma, államtípus, kultúra, birodalom). Ugyanakkor a tartalmak értelmezését szolgáló (tartalmi) kulcsfogalmak az összefüggések feltárására szolgálnak (pl. történelmi idő, változás és folyamatosság, okok és következmények, történelmi források, tények és bizonyítékok, interpretáció, történelmi nézőpont). A történelmi szemlélet alakulása során nem lezárt fogalmakkal dolgozik a pedagógus, hanem a kulcsfogalmak jelentésének folyamatos bővítése, mélyülése történik. Ezek segítik a tanulókat a múltra vonatkozó magyarázatok, következtetések és értékelések megértésében, az ismeretek rendszerezésében, a 
különböző korok és események összehasonlításában, az önálló vélemények megfogalmazásában.

$A z$ öskor címü leckével kapcsolatban érdemes megnézni, hogy milyen kulcsfogalmak tanítását javasolja a kerettanterv, valamint a fejlesztők által közzétett tanmenet (OFI, Kerettantervek). A kerettanterv Az öskor tanegységet is tartalmazó nagyobb témával ( $A z$ öskor és az ókori Kelet - 8 óra) kapcsolatban tesz ajánlást az elvárható kulcsfogalmakra. A tartalmi kulcsfogalmak közül csak az alábbi, nem dőlt betüs fogalmak kapcsolhatók közvetlenül az első leckéhez. A tankönyv tanmenete némileg bővebb fogalomkört javasol a táblázat Ismeretanyag sávjában, dőlt betüvel szedve a nem kerettantervi, kiegészítő adatokat (OFI, Tanmenet).

Értelmező kulcsfogalmak: történelmi idő, ok és következmény, történelmi forrás

Tartalmi kulcsfogalmak: életmód, társadalom, népességrobbanás

Fogalmak: régészet, Homo sapiens, őskőkor, újkőkor, zsákmányoló életmód, mágia, evolúció, Neander-völgyi ember, neolit forradalom

Nevek: Charles Darwin

Topográfia: „termékeny félhold”

Kronológia: Kr. e. 8000 körül

A Process fázis esetében érdemes felvetni azt az egyre több fórumon felmerülő problémát, hogy mi az a tananyagmennyiség, amit ténylegesen számon kérhet a tanár a diákoktól. A köznevelés egészét érintő társadalmi viták állandóan visszatérő eleme ez a kérdéskör, és szinte minden véleménynyilvánító egyetért abban, hogy a legtöbb tantárgy esetében a tananyag mennyisége gátolja a ténylegesen elsajátítható, önálló felhasználásra képes tudás létrejöttét, a kompetenciafejlesztést, amire a legnagyobb szüksége lesz a diáknak a munkaeröpiacon való érvényesüléshez.

Az elvárható ismeretek körének meghatározásában a kerettanterven túl az érettségi vizsgaszabályzat áttekintése is fontos, hiszen a diákok történelemből kötelező vizsgát tesznek a középiskola végén ( $\mathrm{OH}$, Érettségi vizsgaszabályzat). A történelem tantárgy részletes érettségi vizsgakövetelményében a témakörök felsorolásánál sem közép, sem emelt szinten nem szerepel az őskorhoz kapcsolódó anyagrész. Ugyanakkor az elvárható kompetenciák között már számos olyan készséget említ a dokumentum, amelynek fejlesztésére alkalmas ez a lecke (pl. „Fontosabb történelmi fogalmak felismerése, azonosítása, meghatározása forrás alapján, történelmi fogalmak helyes használata” vagy „Események, folyamatok, jelenségek, személyek elhelyezése térben és időben"). A dokumentum továbbá leszögezi, hogy a középszintü érettségi vizsgán a számon kérhető évszámok, személyek, topográfiai adatok és fogalmak megegyeznek az alap- és középfokú történelem kerettantervek adataira és fogalmaira vonatkozó - az adott témakörhöz rendelhetö - tantárgyi követelményeivel. Fontos rögzíteni, hogy az emelt szintü érettségi vizsga írásbeli részének szöveges (kifejtendö) feladatai és szóbeli tételei megoldásához a kerettantervek adatai példaként értelmezendőek. Vagyis abban az esetben, ha a szaktanár alapvetően a középszintü érettségire készíti fel az adott osztályt, akkor a fenti fogalmak (10-15 db) nem fognak előfordulni az érettségi vizsgán. Az emelt szintü érettségire pedig külön órakeretben (fakultáción) készülnek a csoportok.

Úgy véljük, alapvető szemléletváltás szükséges a szaktanárok számára ahhoz, hogy $A z$ öskor címü lecke változatos tananyagát - amely öt oldal terjedelmü - alapvetően a készségfejlesztés és szemléletformálás céljával dolgozza fel az órán, és ne a lexikális jellegü számonkérés érdekében. Hiszen az érettségi „kényszere” nem fenyegeti sem a diákot, sem a szaktanárt. Alapvető pedagógiai hibának tekintjük, ha a téma sokrétű tankönyvi feldolgozását a tanár nem lehetőségnek tekinti a közös munkához, hanem minden részletében számon kérhető müveltséganyagnak. Számos esetben a tankönyvek szerepének félreértéséből fakad a 
diákokat sújtó túlterhelés, hiszen mint láttuk, a kerettantervek és az érettségi követelményeihez képest a tankönyv a kínálati oldalt tartalmazza a tanórai munkához: a bőséges tananyagból történő folyamatos szó szerinti visszakérdezés mellett elsikkadhat a készségfejlesztés és a történelmi szemléletre szoktatás izgalmas kalandja, amely ugyancsak lényeges eleme az iskolai fejlesztő munkának. Erre utal a kerettanterv is, amikor megfogalmazza, hogy az ismeretátadással azonos súllyal kell kezelni a tanulói képességek az ismeretszerzés, tanulás; a kritikai gondolkodás; a kommunikáció; valamint az időben és térben való tájékozódás - fejlesztését, melyet kellően változatos tevékenységformák biztosításával lehet a leghatékonyabban elérni.

A tanmenetek javaslatként megfogalmazzák az adott leckéhez - kerettantervi szempontként - a pedagógiai célokat és a fejlesztési területek négy dimenzióját. Ez a fajta strukturálása a tananyagnak megint csak ajánlásként értelmezhető, hiszen nem is biztos, hogy teljes egészében elvégezhető egy tanórán minden müvelet.

\section{Nevelési-fejlesztési célok, feladatok}

- Az őstörténet forrásainak bemutatása.

- Az evolúció és az emberré válás folyamatának elemzése.

- A mitokondriális Éva elmélete.

- Az őskor két szakaszának, valamint az életmód átalakulásának bemutatása.

- A Willendorfi Vénusz kőanyagából levonható következtetések.

- A neolit forradalom fogalmának értelmezése. Miért a „termékeny félhold” területén alakult ki a letelepült életmód? Hogyan alapozta meg az élelemtermelés kialakulását?

\section{Fejlesztési területek}

\section{Ismeretszerzés, tanulás}

- Forrástípusok felismerése, információgyüjtés és azok rendszerezése: Az őskorra vonatkozó forráscsoportok.

- A történelmi kulcsfogalmak ismerete és alkalmazása: evolúció, őskőkor (paleolitikum), újkőkor (neolitikum), „termékeny félhold”.

- A történelmi fogalmak helyes használata

- Képek, karikatúrák, plakátok, fényképek felhasználása a történelmi ismeretszerzéshez: Korabeli gúnyrajz Darwinról.

\section{Kritikai gondolkodás}

- Történeti események és jelenségek megfigyelése és összehasonlítása: az öskor szakaszainak megadott szempontok mentén való összehasonlítása.

- A földrajzi tényezők szerepének felismerése az emberek életében: A letelepedést elősegítő tényezők.

- Beszámoló készítése

\section{Tájékozódás térben és időben}

- Topográfiai feladatok

- A tanultakkal kapcsolatos helyszínek megmutatása a térképeken: Az öskori lelöhelyek megkeresése a történelmi atlasz térképén.

- Történelmi változások azonosítása és bemutatása térképek segítségével: A Homo sapiens szétrajzása.

- Földrajz: Kontinensek, rasszok; térképolvasás.

Érdekes, hogy a tanmenet a harmadik fejlesztési terület (Kommunikáció) gyakoroltatását a későbbi órákon alkalmazza először. Természetesen a szaktanárnak lehetősége van ettől eltérően, rögtön az első órán a történelmi témával kapcsolatos kommunikáció fejlesztésére is 
(Pl. Az evolúcióelmélettel kapcsolatban megfogalmazódott korabeli és mai érvek önálló vagy csoportos összegyüjtése, majd érthetően és meggyőző módon történő bemutatása).

Mindenképp szót kell ejteni az információfeldolgozás keretén belül a tankönyvben a tanulási folyamatot ugyancsak támogató újabb módszertani eszközről, amelynek szintén a kerettantervben van az alapja. A kerettanterv egy adott témakör kibontását az elvárható Elözetes tudás megfogalmazásával kezdi. A tankönyv ugyanezt a logikát követve a leckéket bevezető kérdések felvetésével indítja ( $A z$ öskor címü leckében pl. Mit tanultunk az általános iskolában az ember kialakulásáról? Milyen körülmények között élt az ősember?). A modern tanuláselméletek (pl. konstruktivizmus) evidenciaként fogadják el, hogy a tanuló elméje nem üres lap, amely a tanítás során megtelik tartalommal. Az új ismeret mindig valamilyen meglévő korábbi tudáselemhez kapcsolódva rögzül. A tanulási folyamat eredményességét nagyban befolyásolja, hogy a diák milyen előzetes (történelmi és egyéb) ismeretekkel rendelkezik, ezért ennek felmérése fontos a tanár számára. Az óra elején felhasználható kérdések aktivizálják a korábban elsajátított tudáselemeket, és elökészítik az új ismeretek beépülését, az árnyaltabb műveltséganyag megkonstruálását.

A tanuló a memorizálás (információk bevésése, tárolása) során felhasználhatja az eddig említett lehetőségeket: a tanár által adott vázlatot, a törzsszöveg vastag betűvel nyomtatott részeit, az összefoglaló fejezet kerettantervi kulcsfogalmait, a térképek, ábrák és táblázatok egyes adatait. Ezek már könnyebben megjegyezhetö, rendezett adathalmazok, és remélhetőleg mindegyikhez kapcsolódnak az órai munka során rögzült egyéb felidézhetö tartalmak.

\section{Output fázis}

Az IPOO harmadik, Output fázisában az információk felhasználása, alkalmazása történik. A történelem órákon zajló számonkérés optimális esetben igazodik a történelem tantárgy érettségi vizsgájának feladattípusaihoz, hogy a tanuló megfelelő jártasságot szerezzen az ismeretek prezentációjában. Kiindulópontunk ismét a középszintü érettségi vizsga feltételrendszere, mert a törzsórák alapvetően erre készítik fel a diákokat. Az emelt szintü vizsgához a fakultációs órakeretet érdemes céltudatosan megtervezni.

Az írásbeli vizsgán a vizsgázóknak egy központi feladatsort kell megoldaniuk, amely két feladattípust tartalmaz. Először egyszerü, rövid választ igénylő feladatokat kell megoldani, amelyek egy forrás (szöveg, kép, diagram stb.) feldolgozását, értelmezését várják el a vizsgázóktól: információkat kell gyüjteni és összehasonlítani, következtetéseket kell megfogalmazni. Bár az őskor témája nem fordulhat elő a vizsgán, a tankönyv következetesen ad hasonló típusú feladatokat ebben a leckében is egy-egy forráshoz kapcsolódva (térkép Melyik földrészről indult meg a Homo Sapiens hosszú vándorlása? / fotó - Milyen célt szolgálhattak a barlangrajzok?). Ennek a feladattípusnak a gyakorlásához, további komplex megoldások kipróbálásához ad segítséget a tankönyvhöz tartozó munkafüzet, amely gyakran táblázatos formában, rendezetten kéri számon a megfelelö információkat, szorosan kapcsolódva a tankönyv tananyagához, illusztrációihoz. Vagyis a szaktanárnak rendelkezésére áll a megfelelö eszköz az információalkalmazás technikájának elsajátíttatásához.

Az írásbeli vizsga második felében szöveges (kifejtendő) feladatokat kell megoldani a diáknak, ahol a vizsgázóknak néhány összefüggő mondatban vagy hosszabb szövegben kell kifejteniük a válaszokat. Ebben az esetben is minden feladatnál forrás segítségével kell megválaszolni a feltett kérdést. A rövid szöveges feladatokhoz szintén a tankönyvi forrásoknál szereplő feladatok ill. a leckék végén szereplő összefoglaló kérdések adnak mintát. A hosszú szöveges feladatokhoz a korábbi évek írásbeli érettségi feladatlapjaiból érdemes válogatni, de a szaktanár is szerkeszthet hasonló kérdéseket. Nélkülözhetetlen az 
alapvető szövegalkotási szabályok megismertetése a tanulókkal a történelem tantárgy keretében is, nem csak magyar nyelvböl.

Egy problémakörnek, folyamatnak, időszaknak összefüggő kifejtését igénylő szóbeli számonkéréshez a tankönyvi témaköröket lezáró összefoglaló vázlat és a kapcsolódó kérdések segíthetnek. Ennek sikeres elsajátításához a pedagógus folyamatos támogató-irányítópéldaadó tevékenysége szükséges, és félévente-évente minden tanulótól egy szóbeli felelet és/vagy prezentáció megkövetelése. Kérdés, hogy erre kizárólag a tanóra idejét veszi-e igénybe a tanár vagy külön alkalmat is felhasznál (beszámoló, próbavizsga).

Meg kell említeni egy olyan módszertani eszközt, amely a hagyományos metodikákban valószínüleg nem található meg, de a tananyag bevésését és számos kompetencia fejlesztését az élménypedagógia révén jelentősen növelheti. A mai diákok fokozott médiaigényére építve javasolják a tankönyv szerzői a törimozi alkalmazásának lehetőségét egy-egy kiválasztott anyagrész esetében. Lényege, hogy egy tanulócsoportnak egy történelmi vitát, dilemmát ötperces videó formájában kell rögzíteni a felmerült alternatív álláspontok ütköztetésével. A tanár által ellenörzött sikeres rövidfilmeket meg is lehet osztani a Nemzeti köznevelési portálon a csoport tagjaival, vagy akár másokkal is. Ez a komplex média- és drámapedagógiai módszer már túlmutat a hagyományos információ-alkalmazás formáin, és egyértelműen a kreatív, produktív feldolgozás felé történő továbblépést jelenti.

\section{Organizációs fázis}

Az IPOO negyedik szempontja, az Organizáció, a tanulásszervezés lehetőségeinek tudatos tervezésére hívja fel a figyelmet az előző három fázis hatékony müködése érdekében. Az intézményesített oktatás keretében hagyományosan frontális formában történik az információk átadása, amit esetenként IKT eszközökkel tesznek színesebbé, felhasználóbaráttá. Ugyanakkor az utóbbi évtizedekben jelentősen átalakult a tanításról-tanulásról vallott szakmai közfelfogás. A modern tanuláselméletek is alátámasztják, hogy a diákok tevékenységének előtérbe kell kerülni a tanórán, és ezzel párhuzamosan a tanári szerepnek is át kell alakulni. Az együttmüködést ösztönző magatartásformák tanórai alkalmazásával a kooperatív tanulás feltételeit mindenképp érdemes kialakítani a történelem órákon is. Bár sok tanár idegenkedik az óra szokásos „rendjének” megbontásától, a tantárgyhoz kapcsolódó fejlesztési területek mindegyike alkalmas a páros vagy csoportos tevékenységforma keretében történő elsajátításra, gyakorlásra. A diák számára is sokkal érdekesebb, ösztönzőbb, ha társaival együttmüködve jut új ismeretekhez, old meg problémát, vagy kutat egy közös témát. Sokkal izgalmasabbá teheti a tanórát, ha egy új elmélet fogadtatását például a drámapedagógia eszközeivel kell feldolgoznia a tanulóknak (pl. az evolúcióelmélettel kapcsolatban megfogalmazódott korabeli és mai érvek ütköztetése vita keretében, esetleg cikk formájában / vagy a neolitikus forradalom életmódváltásának ütköztetése a manapság divatos paleo táplálkozással vita formájában). Számos elönye lehet a tanórai kooperációnak a problémamegoldó, az információkezelő, döntéshozó készségek kialakításában, mert megtapasztalhatják, hogy versenyzés helyett másokkal együttmüködve többet érhetnek el, mint egyedül. Ugyanakkor egymás munkájának jóindulatú kritikusaivá válhatnak, és jelentősen fejlődik kommunikációs képességük is az állandó kérdések, előadások, viták, értékelések ösztönzésére. A tankönyv szerzöi is említik a honlapon található tankönyvismertetőben, hogy az önálló tevékenységformák fejlesztése mellett fontos cél a vitakultúra elsajátítása, és a hagyományos lexikális tudás helyett a hangsúlyt az összefüggések felismertetésére és a kooperatív tevékenységformák alkalmazására kell helyezni. A tankönyv szövegezése ugyanakkor külön nem hívja fel a figyelmet egy-egy téma, probléma, feladat csoportos jellegü megoldására: alapvetően a tanáron múlik, hogy mely feladatok 
megoldásánál lép ki a hagyományos ismeretátadó szerepből, és bízza a diákok együttmüködésére egy feladat megoldását.

\section{Konklúziók}

Az IPOO-modellben körvonalazott tanulási fázisok tudatosítása, szem előtt tartása segítségére lehet a szaktanárnak, akinek alapvető célja, hogy sikeressé tegye a tanulási folyamatot. Ugyanakkor mindegyik fázis sajátos képességek és módszerek érvényesítését igényli. A modell alkalmazása a szervezett tanítási körülmények között zajló tanórára speciális helyzetet jelent, hiszen a tanuló számára a hagyományos iskolai oktatás kevés önállóságot enged: a tanár szervezi az ismeretelsajátítás folyamatát, a tanterv határozza meg a témát, a tankönyv adja a forrásokat. Mégis fontos, hogy a szaktanár határozott lépéseket tegyen annak érdekében, hogy a tanuló fokozatosan alkalmassá váljon az önálló témaválasztásra, az egyéni forráskutatásra, és a választott problémakörrel kapcsolatos információk megfelelő minőségü feldolgozására és prezentálására, hiszen a felsőoktatás és főleg a munkaerőpiac innovatív szereplői egyre inkább ezeket a kompetenciákat várják el leendő munkatársaiktól.

\section{IRODALOM}

Atkinson, H. (2005). Pszichológia. Budapest: Osiris.

Nahalka, I. (2002). A tanulás. Tanulmány. In Falus István (szerk.): Didaktika (Elméleti alapok a tanítás tanulásához) c. könyvében, Budapest: Nemzeti Tankönyvkiadó, 117-158.

Nahalka, I. (1997). Konstruktív pedagógia - Egy új paradigma a láthatáron (I.). Iskolakultúra, 1997/2. http://epa.oszk.hu/00000/00011/00122/pdf/1997-2.pdf

Bessenyei, I. (2007). Tanulás és tanitás az információs társadalomban - e-learning 2.0 és a konnektivizmus (pdf), Budapest.

Virág, I. (2014). Tanuláselméletek és tanitási-tanulási stratégiák. Eger: Eszterházy Károly Főiskola.http://www.tankonyvtar.hu/en/tartalom/tamop412A/20110021_04_tanulaselmeletek_es_tanitasi-tanulasi_strategiak/adatok.html

Mező, F., Mező, K. (2007). Tanulási stratégiák fejlesztése az IPOO-modell alapján. Debrecen: Tehetségvadász Stúdió - Kocka Kör Tehetséggondozó Kulturális egyesület.

OFI, Szakmai beszámoló a TÁMOP 3.1.2-B/13-2013-0001, „A Nemzeti alaptantervhez illeszkedő tankönyv, taneszköz és Nemzeti Köznevelési Portál fejlesztése" című kiemelt projekt tevékenységéről és eredményeiről.

http://ofi.hu/sites/default/files/attachments/Szakmai\%20besz $\%$ C3\%A1mol\%C3\%B3\%20 a\%20T\%C3\%81MOP\%203\%201\%202B\%200224.pdf

Történelem 9. újgenerációs tankönyv. https://player.nkp.hu/play/209834/false/undefined

Nemzeti alaptanterv. http://www.njt.hu/cgi_bin/njt_doc.cgi?docid=149257.218573

Kerettantervek a gimnáziumok 9-12. évfolyama számára. http://kerettanterv.ofi.hu/03_melleklet_9-12/index_4_gimn.html

Tanmenetek a Történelem 9. tankönyvhöz. http://tankonyvkatalogus.hu/site/kiadvany/FI-504010901_1

Történelem, Részletes érettségi vizsgakövetelmény.

https://www.oktatas.hu/pub_bin/dload/kozoktatas/erettsegi/vizsgakovetelmenyek2017/tortene lem_vk_2017.pdf 